\title{
KUALITAS DAN AKTIVITAS ANTIBAKTERI CINCALOK TERHADAP BAKTERI PATOGEN SELAMA WAKTU FERMENTASI
}

\author{
Quality and Antibacterial Activity from Cincalok on Pathogenic Bacteria during \\ Fermentation Time
}

\author{
Kenni Novelia ${ }^{1}$, Ekawati Purwijantiningsih ${ }^{1 *}$, Fransiskus Sinung Pranata ${ }^{1}$ \\ ${ }^{1}$ Prodi Biologi, Fakultas Teknobiologi \\ Universitas Atma Jaya Yogyakarta \\ ekawati.purwijantiningsih@uajy.ac.id
}

\begin{abstract}
Cincalok is a typical West Kalimantan fermented food made from small shrimp called rebon with addition of rice and salt. Fermentation in cincalok is considered complete if the texture of the shrimp used has been crushed and has pink color, prominent sour taste and has distinctive sour aroma appears. The aims of this study to determine the ability of cincalok to inhibit the growth of Escherichia coli and Staphylococcus aureus bacteria and to determine the effect of fermentation time on the quality and antibacterial activity of cincalok. The process of making cincalok in this study was carried out by spontaneous fermentation. The ingredients used were fresh rebon shrimp, rice and salt. The research design used was Completely Randomized Design with variation in fermentation time, on days 0, 7, 14, 21 and 28. The parameter tested in this study include antibacterial activity of cincalok, the number of LAB, pH, total acid, protein content, TVB, and organoleptic qualities. The result of the research that have been carried out show the cincalok was able to inhibit E. coli. The ability of cincalok to inhibit pathogenic bacteria was shown by clear zone around the agar medium. The largest area of inhibition zone was found in cincalok which was fermented for 14 days. Fermentation time variation affects the antibacterial activity against $E$. coli, the number of $L A B, p H$ value, total acid, protein content and TVB of cincalok.
\end{abstract}

Keyword : antibacterial, cincalok, fermentation time, lactic acid bacteria

\begin{abstract}
ABSTRAK
Cincalok merupakan makanan fermentasi khas Kalimantan Barat yang terbuat dari udang rebon dengan penambahan nasi dan garam. Fermentasi pada cincalok dianggap selesai jika tekstur udang yang digunakan telah hancur dan berwarna merah muda, rasa asam yang menonjol serta muncul aroma asam yang khas. Penelitian ini bertujuan untuk mengetahui kemampuan cincalok dalam menghambat pertumbuhan bakteri Escherichia coli dan Staphylococcus aureus serta mengetahui pengaruh waktu fermentasi terhadap kualitas dan aktivitas antibakteri cincalok. Proses pembuatan cincalok pada penelitian ini dilakukan dengan fermentasi spontan. Bahan yang digunakan adalah udang rebon segar nasi dan garam. Rancangan percobaan menggunakan Rancangan Acak Lengkap dengan variasi waktu fermentasi yaitu hari ke-0, 7, 14, 21 dan 28. Parameter uji pada penelitian ini meliputi uji aktivitas antibakteri cincalok, perhitungan jumlah BAL, nilai $\mathrm{pH}$, total asam, kadar protein, TVB, serta uji organoleptik cincalok. Hasil penelitian menunjukkan bahwa cincalok mampu menghambat bakteri $E$. coli. Kemampuan cincalok dalam menghambat bakteri patogen ditunjukkan oleh zona bening di sekitar medium agar. Luas zona hambat paling besar didapatkan pada cincalok yang difermentasi selama 14 hari. Variasi waktu fermentasi berpengaruh terhadap aktivitas antibakteri terhadap E. coli, jumlah BAL, nilai $\mathrm{pH}$, total asam, kadar protein serta TVB cincalok.
\end{abstract}

Kata Kunci : antibakteri, bakteri asam laktat, cincalok, waktu fermentasi 


\section{PENDAHULUAN}

Cincalok atau cincaluk merupakan salah satu makanan hasil fermentasi khas Kalimantan Barat yang berbahan dasar udang kecil dengan penambahan nasi serta garam kemudian difermentasi dalam wadah tertutup. Fermentasi cincalok terjadi selama 1 sampai 2 minggu di dalam botol yang tertutup rapat (Irianto, 2013). Fermentasi pada cincalok dinilai selesai jika tekstur udang yang digunakan telah hancur, menghasilkan udang yang berwarna merah muda, rasa asam yang menonjol, dan muncul aroma asam yang khas. Kualitas cincalok dapat dinilai melalui uji organoleptik berupa uji kenampakan berdasarkan warna, bentuk, bau, dan rasa. Penurunan kualitas akhir cincalok dapat diketahui dengan uji total volatile base (TVB) yang merupakan suatu uji untuk melihat perubahan mutu suatu produk tinggi protein dengan mengukur senyawa basa yang menguap (Syaputra et al., 2007).

Fermentasi pada cincalok terjadi secara spontan dengan memanfaatkan mikrobia alami dari lingkungan, salah satu mikrobia yang memegang peran penting dalam fermentasi adalah bakteri asam laktat (BAL). Mikrobia penghasil asam laktat yang biasa ditemui pada cincalok adalah
Lactobacillus sp. dan Streptococcus sp., selain itu dapat dijumpai beberapa mikrobia lainnya seperti jamur, bakteri patogen, dan bakteri pembusuk yang dapat menurunkan kualitas cincalok (Achmad et al., 2013). Penelitian yang dilakukan oleh Yanti dan Dali (2013) menunjukkan bahwa genus BAL yang terdapat pada produs fermentasi spontan yakni Lactobacillus, Streptococcus, Enterococcus, Pediococcus, Tetragenococcus, Leuconostoc, dan Lactococcus.

Waktu fermentasi dapat memengaruhi jumlah koloni bakteri yang terdapat pada produk fermentasi. Hal tersebut disebabkan karena BAL menghasilkan asam yang dapat berperan sebagai antibakteri dan mampu mengganggu sistem transportasi nutrisi bakteri patogen dan pembusuk sehingga tidak dapat melakukan aktivitas metabolismenya (Mardalena, 2016). Asam yang dihasilkan pada produk fermentasi menunjukkan kehadiran BAL yang mampu meningkatkan kualitas produk fermentasi (Khairina et al., 2017). Jumlah asam pada produk fermentasi semakin meningkat saat BAL berada pada fase eksponensial (Mardalena, 2016). Selain asam, BAL menghasilkan senyawa antibakteri seperti bakteriosin, karbondioksida dan hidrogen 
J.Gipas, November 2020, Volume 4 Nomor 2

ISSN 2599-0152 eISSN 2599-2465

http://jos.unsoed.ac.id/index.php/jgps

peroksida sehingga dapat meningkatkan masa simpan produk (Holzapfel et al., 2001).

Bakteri asam laktat yang terdapat pada makanan fermentasi dapat dimanfaatkan untuk menghambat pertumbuhan bakteri Gram positif dan Gram negatif yang dapat menyebabkan penyakit gastroenteritis (Karlina et al., 2013). Bakteri Escherichia coli merupakan bakteri Gram negatif yang dapat menyebabkan gastroenteritis dan mampu hidup dalam kondisi aerob atau fakultatif anaerob (Melliawati, 2009). Bakteri Staphylococcus aureus adalah bakteri Gram positif yang menjadi penyebab keracunan makanan karena mampu memproduksi toksin yang mampu bertahan pada suhu tinggi dan suhu rendah (Jawetz et al., 2001). Hasil penelitian menunjukkan BAL yang diisolasi dari cincalok dapat menghambat pertumbuhan bakteri patogen (Samboja et al., 2019). Penelitian ini berbeda dengan penelitian Samboja et al. (2019) karena pada penelitian ini yang diuji adalah kemampuan produk cincalok dalam menghambat pertumbuhan bakteri patogen selama waktu fermentasi.

Penelitian ini bertujuan untuk mengetahui kemampuan cincalok dalam menghambat pertumbuhan bakteri E. coli dan S. aureus serta mengetahui pengaruh waktu fermentasi terhadap kualitas dan aktivitas antibakteri pada makanan fermentasi cincalok.

\section{METODE}

\section{Tempat dan waktu Penelitian}

Penelitian dilakukan di Laboratorium Teknobio-Pangan dan Laboratorium Produksi, Fakultas Teknobiologi, Universitas Atma Jaya Yogyakarta pada bulan Februari sampai dengan Oktober 2019.

\section{Alat dan bahan}

Alat-alat yang digunakan dalam penelitian ini adalah erlenmeyer, inkubator Memmert, laminair air flow Omega SV 1200 SG, microwave Electrolux EMM2007X, perforator, pH meter Eutech 1205609, pipet ukur Pyrex, mikropipet dengan merk Socorex, labu ukur Pyrex $100 \mathrm{~mL}$, mikrotip Axygen, botol jam steril, vortex Mixer VM300, lampu spritus, pro pipet, buret Pyrex, statif, handcounter, botol jam, timbangan analitik Phoenix Instrument, cawan petri Charuzu, dan color reader, refrigerator Sharp, autoklaf Hirayama Hiclave HVE 500, lemari asam, kompor Grande RI-7112A.

Bahan-bahan yang digunakan adalah udang rebon yang diperoleh dari salah satu pasar swalayan di Kota Harapan Indah, garam, nasi, medium Nutrient Agar (NA), de Man Rogosa Sharpe Agar (MRSA), Nutrient Broth (NB), $\quad 0,5 \% \mathrm{CaCO}_{3}$, indikator 
fenolftalein (PP), Brilliant Green Bile $2 \%$

Broth (BGLB), Eosin Methylene Blue Agar (EMBA), Mannitol Salt Agar (MSA), alkohol $70 \%$, aqudes, $\mathrm{H}_{2} \mathrm{SO}_{4}$ pekat, $\mathrm{NaOH}$ tio, $\mathrm{HCl} 0,02 \mathrm{~N}, \mathrm{H}_{3} \mathrm{BO}_{3}$, katalis $\mathrm{N}$, larutan $\mathrm{H}_{2} \mathrm{O}_{2} 3 \%$, NaOH 0,1 N, Buffered peptone water (BPW), natrium benzoat, kultur bakteri E. coli dan kultur bakteri $S$. aureus.

Penelitian ini menggunakan Racangan Acak Lengkap dengan 5 variasi waktu fermentasi yakni hari ke-0, 7, 14, 21 dan 28. Pengulangan dilakukan sebanyak 3 kali dalam setiap perlakuan. Tahapan penelitian adalah sebagai berikut:

1. Pembuatan cincalok

Cincalok dibuat dengan menggunakan udang rebon, garam, dan nasi dengan perbandingan 7:1:2. Udang rebon dicuci bersih dengan aquades steril kemudian dicampur hingga rata dengan garam dan nasi, selanjutnya dimasukkan ke dalam botol jam dan disimpan selama 28 hari untuk membiarkan proses fermentasi berlangsung (Dyastuti et al., 2013).

2. Pengujian aktivitas antibakteri cincalok

Sumuran dibuat menggunakan perforator pada medium Nutrient Agar yang sudah memadat, kemudian sebanyak $20 \mu \mathrm{L}$ sampel dimasukkan ke dalam sumuran. Pada salah satu sumuran dimasukkan natrium benzoat yang berfungsi kontrol. Inkubasi dilakukan selama 24 jam pada suhu $37{ }^{\circ} \mathrm{C}$ (Singkoh. 2011). Zona bening yang terbentuk diukur dengan penggaris dan dihitung dengan rumus:

$$
\mathrm{LZH}=\frac{(\mathrm{d} 2)^{2}-(\mathrm{d} 1)^{2}}{4} \times \frac{22}{7}
$$

Keterangan:

$\mathrm{d} 2$ = diameter zona hambat

$\mathrm{d} 1$ = diameter sumuran

\section{Pengujian jumlah BAL}

Pengujian jumlah BAL dilakukan untuk memastikan bahwa BAL berperan pada proses fermentasi cincalok serta mengetahui apakah jumlah BAL yang terdapat pada cincalok tersebut memenuhi kriteria sebagai produk pangan fermentasi yang baik untuk dikonsumsi.

Sampel cincalok dari fermentasi hari ke-0, 7, 14, 21, dan 28 diencerkan dengan seri pengenceran $10^{-1}$ hingga $10^{-12}$. Sampel sebanyak $1 \mathrm{~mL}$ dari dari pengenceran $10^{-5}$ hingga $10^{-12}$ dimasukkan ke dalam petri steril kemudian medium MRS agar yang telah ditambahkan dengan $\mathrm{CaCO}_{3}$ dituang ke dalam petri dengan metode pour plate, selanjutnya petri digoyang membentuk angka 8. Petri kemudian diinkubasi selama 48 jam pada suhu $37^{\circ} \mathrm{C}$. Viabilitas BAL yang hidup kemudian dikalikan dengan faktor pengenceran yang digunakan. Koloni yang dihitung adalah yang memenuhi persyaratan yakni 25-250 koloni pada setiap petri (Hasanah, 2014).

Perhitungan dilakukan dengan rumus sebagai 
berikut:

$$
\begin{gathered}
\text { ALT }= \\
\frac{\Sigma \mathrm{C}}{\left[\left(1 \times \mathrm{n}_{1}\right)+\left(0,1 \times \mathrm{n}_{2}\right)+\left(0,01 \times \mathrm{n}_{3}\right) \times \mathrm{d}\right\}}
\end{gathered}
$$

Keterangan:

$\mathrm{C}=$ jumlah koloni dari tiap petri

$\mathrm{n}_{1}=$ jumlah petri dari pengenceran

pertama yang memenuhi syarat

$\mathrm{n}_{2}=$ jumlah petri dari pengenceran

kedua yang memenuhi syarat

$\mathrm{d}=$ faktor pengenceran pertama yang

memenuhi syarat

4. Pengujian kualitas cincalok

Uji kualitas cincalok meliputi uji $\mathrm{pH}$ dan total asam (Septiani et al., 2013), kadar protein (Sudarmadji dkk., 1997), TVB (Suwetja, 1993), serta uji organoleptik. Pengujian organoleptik dilakukan oleh panelis perseorangan dengan mengamati parameter aroma, tekstur dan warna. Adapun kriteria pengujian adalah aroma: 1 (khas udang) - 5 (asam), tekstur: 1 (udang dan nasi utuh) - 5 (udang dan nasi hancur + cairan), warna: 1 (abu-abu) - 5 (merah muda hingga oranye). Pengujian dilakukan pada hari ke- 0, 7 , 14, 21 dan 28, kecuali kadar protein dan TVB yang dilakukan pada hari ke- 0 dan 28.

\section{Analisis Data}

Analisis data dilakukan dengan program SPSS 15.00 menggunakan ANOVA dengan tingkat kepercayaan 95\% dan analisis dilanjutkan menggunakan uji DMRT (Duncan's Multiple Range Test) dengan tingkat kepercayaan $95 \%$ jika hasil ANOVA menunjukkan beda nyata.

\section{HASIL DAN PEMBAHASAN}

\section{a. Aktivitas antibakteri cincalok}

Cincalok memiliki kemampuan yang berbeda dalam menghambat bakteri E. coli dan S. aureus (Tabel 1). Penghambatan terhadap bakteri uji ditunjukkan dengan adanya zona bening di sekitar sumuran (Gambar 1). Sama seperti natrium benzoat, cincalok tidak mampu menghambat pertumbuhan bakteri $S$. aureus tetapi dapat menghambat pertumbuhan bakteri E. coli. Hasil tersebut sesuai dengan teori Radji (2011) dan Wangkanusa (2016) yang menyatakan ketebalan dinding sel bakteri Gram negatif berbeda dengan Gram positif sehingga memiliki kekuatan penghambatan yang berbeda. Penghambatan pertumbuhan terhadap E. coli oleh cincalok lebih rendah dibandingkan natrium benzoat yang digunakan sebagai kontrol. Pada industri pangan, natrium benzoat biasa digunakan sebagai pengawet pangan. 
Tabel 1. Diameter (mm) dan Luas Zona Hambat $\left(\mathrm{cm}^{2}\right)$ Cincalok Terhadap Bakteri $E$. coli dan $S$. aureus Selama Fermentasi

\begin{tabular}{lllll} 
& \multicolumn{2}{l}{ Diameter zona hambat } & \multicolumn{2}{l}{ Luas Zona Hambat } \\
\cline { 2 - 5 } & $\begin{array}{l}\text { S.aureus } \\
(\mathbf{m m})\end{array}$ & $\begin{array}{l}\boldsymbol{E} \text {. coli } \\
(\mathbf{m m})\end{array}$ & $\begin{array}{l}\text { S.aureus } \\
\left.\mathbf{( c m}^{\mathbf{2}}\right)\end{array}$ & $\begin{array}{l}\boldsymbol{E} \text {. coli } \\
\left(\mathbf{c m}^{\mathbf{2}}\right)\end{array}$ \\
\hline 0 & 0 & 0 & 0 & $0 \pm 0^{\mathrm{a}}$ \\
7 & 0 & 7,33 & 0 & $0,23 \pm 0,70^{\mathrm{ab}}$ \\
14 & 0 & 8,67 & 0 & $0,40 \pm 0,75^{\mathrm{b}}$ \\
21 & 0 & 7,67 & 0 & $0,27 \pm 0,70^{\mathrm{ab}}$ \\
28 & 0 & 7,67 & 0 & $0,27 \pm 0,70^{\mathrm{ab}}$ \\
Natrium & 0 & 13 & 0 & $1,21 \pm 0,32^{\mathrm{c}}$ \\
benzoat & & & & \\
\hline
\end{tabular}

Keterangan: Angka yang diikuti dengan huruf yang sama pada satu kolom menunjukkan tidak terdapat beda nyata pada taraf kepercayaan $95 \%$

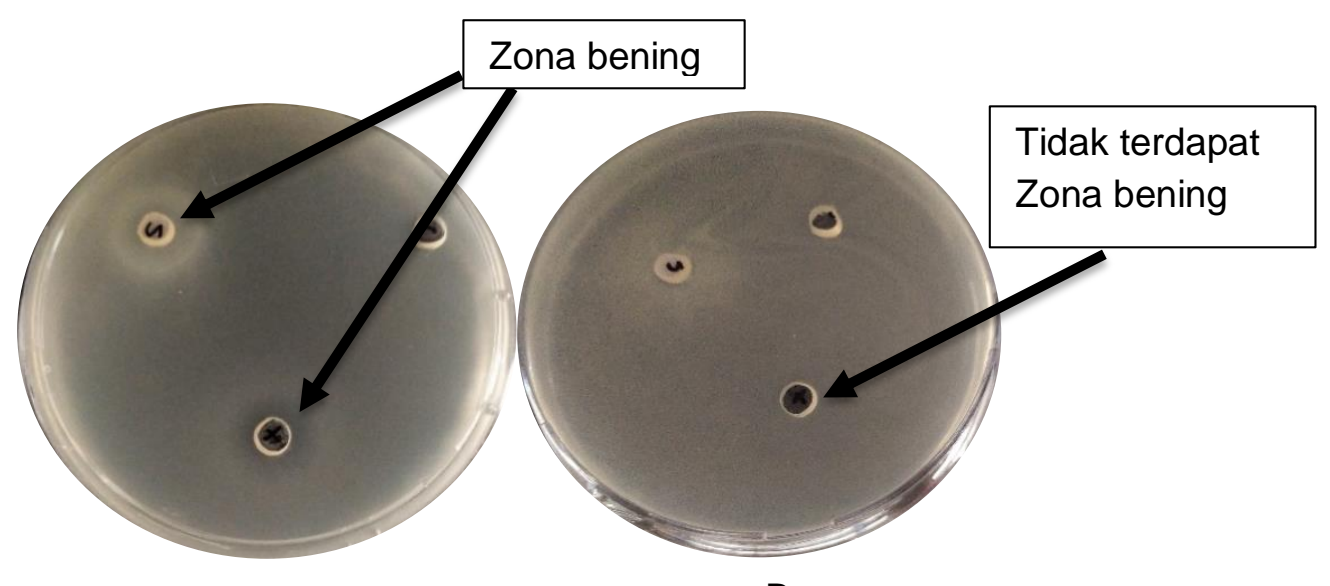

A

$\mathrm{B}$

Gambar 1. Uji Penghambatan Cincalok Terhadap E. coli (A) dan S. aureus (B)

\section{b. Jumlah bakteri asam laktat pada} cincalok

Jumlah BAL paling tinggi terdapat pada fermentasi cincalok hari ke- 14, kemudian mengalami penurunan pada hari ke- 21 (Gambar 2). Hasil tersebut sesuai dengan teori Cakrawati dan Kusumah (2016) yang menyatakan setelah fase adaptasi, BAL akan memasuki fase log yang menyebabkan pertambahan jumlah BAL dan penurunan $\mathrm{pH}$ menjadi semakin asam, kemudian akan terjadi penurunan jumlah BAL karena menipisnya nutrisi bagi BAL yang diiringi oleh kenaikan pH. Jumlah BAL hari ke- 28 semakin mengalami penurunan, hal tersebut dapat disebabkan berkurangnya sumber nutrien sehingga terjadi fase kematian bakteri dan menyebabkan penurunan jumlah bakteri (Rachman et al., 2016) 


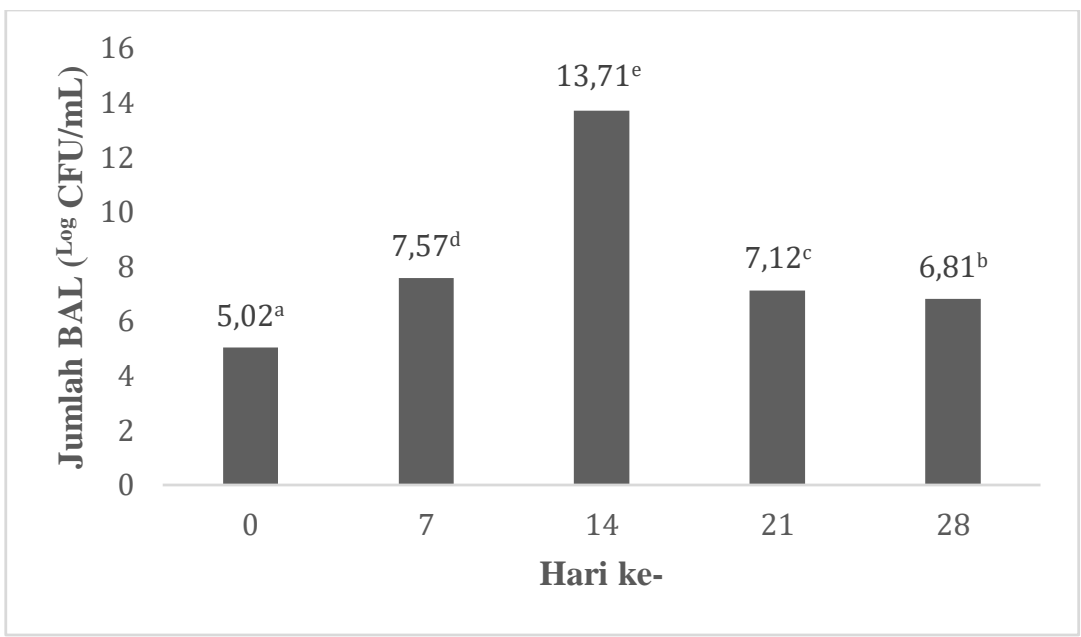

\section{Gambar 2. Jumlah BAL $(\log$ CFU/mL) Cincalok Selama Waktu Fermentasi}

Jumlah BAL yang semakin tinggi menunjukkan semakin baik produk untuk dikonsumsi. Hasil tersebut didukung oleh penelitian Koesoemawardani dan Yuliana (2009), yang mendapatkan jumlah BAL pada fermentasi rusip berkisar antara 7,62-10,23 $\log \mathrm{CFU} / \mathrm{mL}$. Jumlah BAL yang baik untuk dikonsumsi adalah $10^{7}-10^{9} \log \mathrm{CFU} / \mathrm{mL}$, dan jumlah yang semakin tinggi menunjukkan semakin baik suatu produk untuk dikonsumsi (Ismawati, 2018).
Nilai pH cincalok mengalami penurunan hingga hari ke-7 dan 14. Nilai pH paling rendah pada hari ke-14. Penurunan nilai $\mathrm{pH}$ menunjukkan terjadinya proses fermentasi. Suatu produk fermentasi layak konsumsi jika memiliki nilai $\mathrm{pH}$ berkisar antara 4,4-8,0 yang masih memungkinkan BAL untuk tumbuh (Rinto, 2018). Hasil tersebut didukung oleh Khairina et al. (2017) yang menyatakan $\mathrm{pH}$ makanan fermentasi kung-som yang mirip dengan ronto dan cincalok adalah 4,5-5,5.

\section{c. Nilai pH dan total asam cincalok}

Tabel 2. Nilai pH dan Total Asam (\%) Cincalok Selama Waktu Fermentasi

\begin{tabular}{lll}
\hline Hari ke- & pH & Total Asam (\%) \\
\hline 0 & $8,47 \pm 0,32^{\mathrm{d}}$ & $0,01 \pm 0^{\mathrm{a}}$ \\
7 & $5,57 \pm 0,17^{\mathrm{c}}$ & $0,13 \pm 0^{\mathrm{b}}$ \\
14 & $4,96 \pm 0,15^{\mathrm{a}}$ & $0,20 \pm 0^{\mathrm{d}}$ \\
21 & $5,01 \pm 0,06^{\mathrm{b}}$ & $0,18 \pm 0,01^{\mathrm{c}}$ \\
28 & $5,01 \pm 0,01^{\mathrm{b}}$ & $0,18 \pm 0,01^{\mathrm{c}}$ \\
\hline
\end{tabular}

Keterangan: Angka yang diikuti dengan huruf yang sama pada satu kolom 
menunjukkan tidak terdapat beda nyata pada taraf kepercayaan $95 \%$

Nilai total asam yang diperoleh berbanding terbalik dengan nilai $\mathrm{pH}$ (Tabel 2). Semakin tinggi jumlah BAL pada suatu produk fermentasi, maka semakin tinggi total asam yang dihasilkan seiring dengan penurunan nilai $\mathrm{pH}$ dan produk menjadi semakin asam. Peningkatan total asam yang terjadi pada hari ke-14 dapat disebabkan oleh penguraian karbohidrat menjadi senyawa yang lebih sederhana seperti asam laktat, asam propionat, asam asetat dan etil alkohol yang berperan memberi rasa dan aroma asam pada produk (Arfianty et al., 2017).

Pada hari ke-21 terjadi penurunan total asam, hasil tersebut dapat terjadi akibat penguapan asam asetat (Widyasaputra dan Yuwono, 2013). Proses fermentasi yang semakin lama akan meningkatkan jumlah asam yang mudah menguap (Agustina, 2014). Bakteri asam asetat yang memanfaatkan asam laktat dalam produk untuk proses pertumbuhannya kemudian mengubah asam laktat menjadi karbondioksida $\left(\mathrm{CO}_{2}\right)$ dan air. Hal tersebut mengakibatkan terjadinya penurunan total asam (Mozzi et al., 2016; Pangastuti 2018).

\section{d. Kadar Protein Cincalok}

Kadar protein cincalok pada hari ke28 mengalami penurunan dibandingkan hari ke-0 (Gambar 3). Turunnya nilai protein selama waktu fermentasi menunjukkan proses penguraian protein oleh bakteri selama fermentasi. Hasil tersebut sesuai dengan teori yang menyatakan bakteri mendegradasi sebagian protein menjadi senyawa yang lebih sederhana dan bersifat volatil selama proses fermentasi setelah habisnya sumber karbohidrat (Zunaidar et al., 2016). Waktu fermentasi yang semakin lama, meningkatkan jumlah protein yang terdegradasi dan menyebabkan kadar protein menurun (Andarti dan Wardani, 2015).

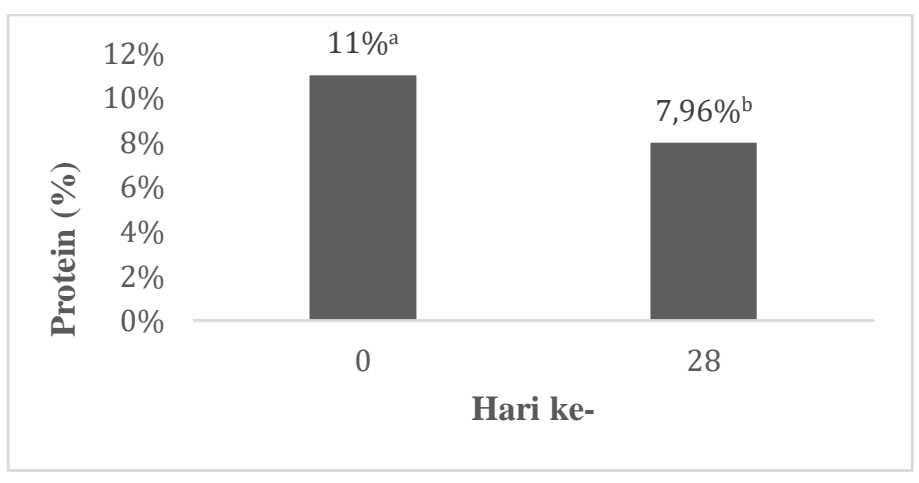




\section{Gambar 3. Perubahan Kadar Protein (\%) Cincalok Selama Fermentasi}

\section{e. Analisis total volatile base cincalok}

Uji TVB digunakan untuk mengukur basa mudah menguap seperti amonia $\left(\mathrm{NH}_{3}\right)$ dan trimetilamina (TMA) yang terdapat pada ikan dan krustasea yang dapat dijadikan acuan pembusukan makanan dengan protein tinggi (Zummah dan Wikandari, 2013). Total Volatile Base dapat terbentuk sebagai hasil dari pemecahan protein menjadi senyawa yang lebih sederhana yang disebabkan oleh aktivitas mikrobia pada bahan pangan.

Hasil penelitian menunjukkan bahwa nilai TVB cincalok pada hari ke-0 dan ke-28 berbeda nyata (Gambar 4). Semakin lama waktu fermentasi, TVB akan semakin meningkat. Berdasarkan kandungan TVB, pada hari ke-28 cincalok masih layak dikonsumsi. Nilai TVB yang diperoleh pada penelitian ini lebih rendah dibandingkan hasil penelitian yang dilakukan oleh Barodah et al. (2017) pada produk fermentasi ikan lele yang memiliki nilai TVB pada hari ke- 12 sebesar 218,3 mg N/100 gram. Nilai maksimum TVB untuk produk ikan segar dan dinyatakan layak untuk dikonsumsi adalah $300 \mathrm{mg}$ N / 100 gram sampel (Direktorat Jenderal Perikanan, 2000).

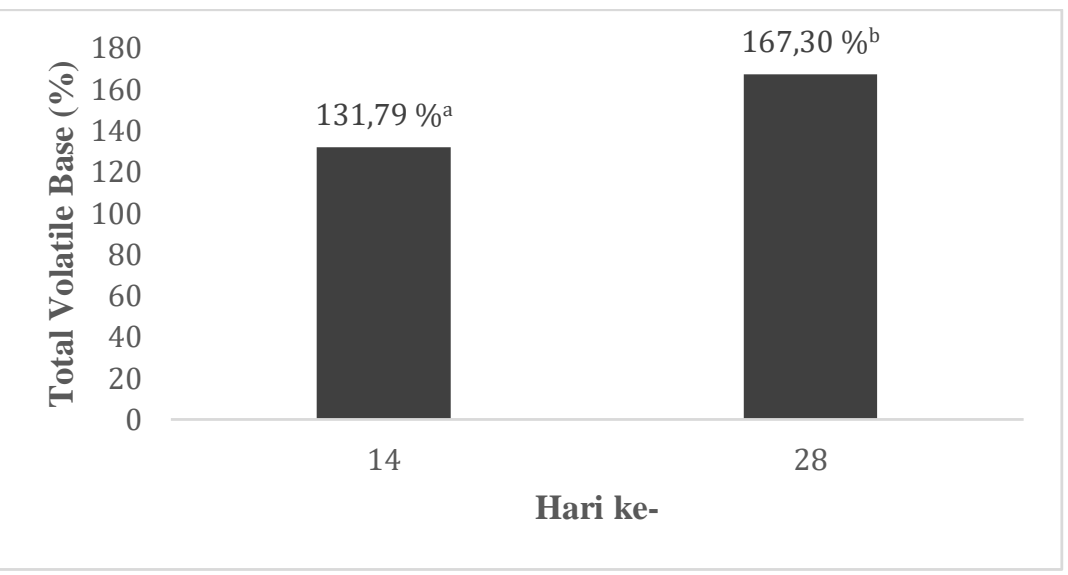

Gambar 4. Perubahan Total Volatile Base Cincalok Selama Waktu Fermentasi

\section{f. Hasil uji organoleptik cincalok}

Berdasarkan pengamatan yang dilakukan, diketahui bahwa aroma pada fermentasi cincalok hari ke-0 adalah aroma khas udang, namun pada hari ke-7 aroma menjadi sedikit asam. Pengamatan fermentasi 
cincalok pada hari ke-14 menimbulkan bau asam yang lebih kuat dan relatif sama hingga hari ke-28 (Tabel 3). Tekstur cincalok pada pengamatan hari ke-0 menunjukkan nasi dan udang yang masih utuh dan warna abu-abu, pada hari ke-7 tekstur udang dan nasi mulai hancur dengan warna merah muda pucat, kemudian hari ke- 14 tekstur udang dan nasi lebih hancur serta terdapat sedikit cairan.
Warna yang dihasilkan pada fermentasi hari ke- 14 adalah merah muda dan sedikit oranye. Pengamatan hari ke-21 hingga hari ke- 28 menunjukkan tekstur udang dan nasi yang lebih hancur dari hari ke-14 dan cairan yang dihasilkan lebih banyak dengan warna udang merah muda dan oranye lebih terang (Gambar $5)$.

Tabel 3. Hasil Uji Organoleptik Cincalok Selama Fermentasi

\begin{tabular}{cccc}
\hline Hari ke- & Aroma & Tekstur & Warna \\
\hline 0 & 1 & 1 & 1 \\
7 & 3 & 3 & 3 \\
14 & 5 & 4 & 4 \\
21 & 5 & 5 & 5 \\
28 & 5 & 5 & 5 \\
\hline
\end{tabular}

Keterangan:

Aroma $=1$ (khas udang) -5 (asam)

Tekstur $=1$ (udang dan nasi utuh) -5 (udang dan nasi hancur + cairan)

Warna $\quad=1($ abu-abu $)-5$ (merah muda hingga oranye $)$

Hasil yang diperoleh terhadap uji organoleptik cincalok sesuai dengan teori yang dikemukakan oleh Khairina et al. (2017), yang menyatakan aroma fermentasi pada produk fermentasi yang mirip cincalok mulai muncul pada hari ke- 8 , aroma semakin kuat hingga hari ke- 12. Aroma yang dihasilkan akan menjadi lebih asam dan cenderung tidak berubah hingga hari terakhir pengamatan. Tekstur yang diperoleh pada pengamatan hari ke- 12 adalah sekitar $50 \%$ udang dan $80 \%$ nasi mulai hancur dan terdapat sedikit cairan, kemudian tekstur udang pada hari terakhir pengamatan adalah seperti bubur dengan cairan yang lebih banyak akibat hancurnya beras dan udang. 


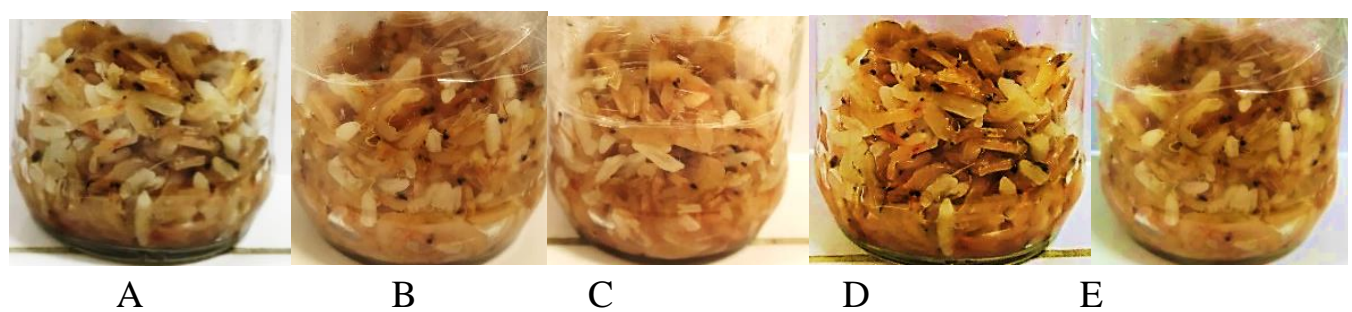

\section{Gambar 5. Hasil Fermentasi Cincalok hari ke- 0 (A), hari ke- 7 (B), hari ke- 14 (C) hari ke- 21 (D), dan hari ke- 28 (E)}

\section{KESIMPULAN}

Produk

cincalok

memiliki

kemampuan

dalam

menghambat

pertumbuhan bakteri $E$. coli namun tidak mampu menghambat bakteri $S$. aureus. Fermentasi selama 14 hari menghasilkan aktivitas antibakteri terhadap E. coli terbesar. Variasi waktu fermentasi berpengaruh terhadap aktivitas antibakteri terhadap $E$. coli, viabilitas BAL, nilai $\mathrm{pH}$, total asam, kadar protein serta TVB cincalok.

\section{DAFTAR PUSTAKA}

Achmad, D. I., Nofiani, R., dan Ardiningsih, P. 2013.

Karakterisasi bakteri asam laktat Lactobacillus sp. $\mathrm{RED}_{1}$ dari cincalok formulasi. Jurnal Kimia Katulistiwa 1(1): 1 5.

Agustina, S. 2014. Pengaruh kuantitas garam pada pembuatan bekasam terhadap tingkat keasaman, degradasi protein, dan pelunakan tulang ikan. Skripsi S-1. Politeknik Negeri Sriwijaya, Palembang.

Andarti, I. Y. dan Wardani, A. K. 2015. Pengaruh lama fermentasi terhadap karakteristik kimia, mikrobiologi, dan organoleptik miso kedelai hitam (Glycine max (L)). Jurnal Pangan dan Agroindustri 3(3): 889 - 898.

Arfianty, B. N., Farisi, S., dan Ekowati, C, N. 2017. Dinamika populasi bakteri dan total asam pada fermentasi bekasam ikan patin (Pangasius hypopthalmus). Jurnal Biologi Eksperimen dan Keanekaragaman Hayati 4(2): $43-49$.

Barodah, L. L., Sumardianto., dan Susanto, E. 2017. Efektivitas serbuk Sargassum polycystum sebagai antibakteri pada ikan lele (Clarias sp.) selama penyimpanan dingin. Jurnal Pengolahan dan Bioteknologi Hasil Perikanan 6(1): 10 - 20.

Cakrawati, D. dan Kusumah, M. A. 2016. Pengaruh penambahan $\mathrm{CMC}$ sebagai senyawa penstabil terhadap yoghurt tepung gembili. Agrointek 10(2): 76 - 84.

Direktorat Jenderal Perikanan. 2000. Statistik Perikanan Indonesia. Direktorat Perikanan, Jakarta.

Hasanah, U. 2014. Bakteri asam laktat dari daging ikan peda sebagai agen probiotik dan enzim kolesterol reduktase. Jurnal Keluarga Sehat Sejahtera 12(23): 1 - 8. 
Holzapfel, W. H., Haberer, P., Geisen, R., Bjorkroth, J., dan Schillinger, U. 2001. Taxonomy and important features of probiotic microorganisms in food and nutrition. The American Journal of Clinical Nutrition 75(2): 365 - 373.

Irianto, H. E. 2013. Produk Fermentasi Ikan. Penebar Swadaya, Jakarta.

Ismawati, D. 2018. Isolasi dan karakterisasi bakteri asam laktat (BAL) proteolitik dari kefir. Skripsi S-1. Fakultas Matematika dan Ilmu Pengetahuan Alam Universitas Lampung, Lampung.

Jawetz, E., Melnick, J. L., dan Adelberg, E. A. 2001. Mikrobiologi Kedokteran. Salemba Medika, Jakarta.

Khairina, R., Cahyanto, M. R., Utami, T., dan Rahardjo, S. 2017. Karakteristik fisikawi, kimiawi, dan mikrobiologis ronto selama penyimpanan. Jurnal Pengolahan Hasil Perikanan Indonesia 19(3): 348 - 355.

Koesoemawardani, D. dan Yuliana, N. 2009. Karakter rusip dengan penambahan kultur kering: Streptococcus sp. Skripsi S-1. Fakultas Pertanian Universitas Lampung, Lampung.

Mardalena. 2016. Fase pertumbuhan isolat bakteri asam laktat (BAL) tempoyak asal Jambi yang disimpan pada suhu kamar. Jurnal Sains Peternakan Indonesia 11(1): 58 - 66.

Melliawati, R. 2009. Escherichia coli dalam kehidupan manusia. Jurnal Biotrends 4(1): 10 - 14 .

Mozzi, F., Raya, R. R., dan Vignolo, G. M. 2016. Biotechnology of Lactic Acid Bacteria: Novel Application. John Wiley \& Sons, Ltd., United Kingdom.
Pangastuti, M. S. 2018. Perbaikan waktu fermentasi dan kualitas biji kakao (Theobroma cacao L.) dengan penambahan variasi konsentrasi inokulum campuran. Skripsi S-1. Fakultas Teknobiologi Universitas atma Jaya Yogyakarta, Yogyakarta.

Rachman, S. D., Safari, A. Fazli., Kamara, S. D., Sidik, A., Udin, L. Z., dan Ishmayana, S. 2016. Produksi penisilin oleh Penicillium chrysogenum L112 dengan variasi kecepatan agitasi pada fermentor 1 L. Jurnal Ilmiah Farmasi 4(2): 1 - 6 .

Radji, M. 2011. Mikrobiologi. Buku kedokteran ECG, Jakarta.

Rinto. 2018. Manfaat Fungsional Produk Fermentasi Hasil Perikanan Indonesia. Unsri Press, Palembang.

Samboja, L.D.G., Purwijantiningsih, E., Yuda, P. 2019. Identifikasi dan uji aktivitas antibakteri isolat bakteri asam laktat dari fermentasi udang (cincalok) terhadap Vibrio parahaemolyticus dan Listeria monocytogenes. JLFS 3(1):11-20

Septiani, A. H., Kusrahayu., dan Legowo, A. M. 2013. Pengaruh penambahan susu skim pada proses pembuatan frozen yogurt yang berbahan dasar whey terhadap total asam, $\mathrm{pH}$ dan jumlah bakteri asam laktat. Animal Agriculture Journal 2(1): 225 - 231.

Singkoh, M. F. O. 2011. Aktivitas antibakteri ekstrak alga laut (Caulerpa racemose) dari perairan pulau Nain. Jurnal Perikanan dan Kelautan Tropis 7(3): 123 - 127.

Sudarmadji, S., Haryono, B. dan Suhardi. 1997. Prosedur Analisa untuk Bahan Makanan dan Pertanian. Liberty, Yogyakarta. 
Suwetja, K. I. 1993. Metode Penentuan Mutu Ikan. Unsrat Press, Manado.

Syaputra, D., Ibrahim, R. dan Poernomo, D. 2007. Produk fermentasi ikan dari cacing kapal Bactronophorus sp. segar. Jurnal Sumberdaya Perairan 1(1): 12 - 14.

Yanti, D. I. W. dan Dali, F. A. 2013. Karakterisasi bakteri asam laktat yang diisolasi selama fermentasi bekasang. Jurnal Pengolahan Hasil Perikanan Indonesia 16(2): 133 - 141.

Wangkanusa, D., Lolo, W. A., dan Wewengkang, D. S. 2016. Uji aktivitas antibakteri dari ekstrak daun prasman (Eupatorium triplinerve Vahl.) terhadap pertumbuhan bakteri Staphylococcus aureus dan Pseudomonas aeruginosa. Pharmacon Jurnal Ilmiah Farmasi 5(4): 203 - 210.
Widyasaputra, R. dan Yuwono, S. S. 2013. Pengaruh fermentasi alami chips terhadap sifat fisik tepung ubi jalar putih (Ipomoea batatas L) terfermentasi. Jurnal Pangan dan Agroindustri 1(1): 78 - 89.

Zuidar, A. S., Rizal, S., dan Widyastuti, K. 2016. Pengaruh jenis ikan dan konsentrasi garam pada rebung ikan terfermentasi. Jurnal Kelitbangan 4(2): 181 - 194.

Zummah, A. dan Wikandari, P. 2013. Pengaruh waktu fermentasi dan penambahan kultur starter bakteri asam laktat Lactobacillus plantarum B1765 terhadap mutu bekasam ikan bandeng (Chanos chanos). Unesa Journal of Chemistry 2(3): 14-24 